\title{
Textiles Beyond the MFA Phase-Out
}

Dean Spinanger

CSGR Working Paper No. 13/98

July 1998
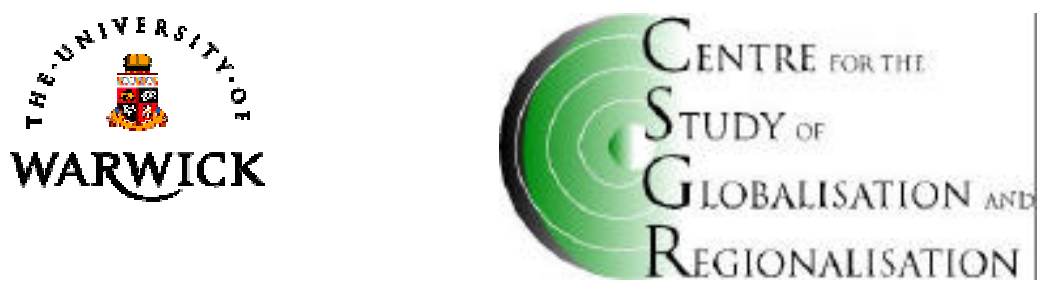

E.S.R.C
ECONOMIC
\&SOCIAL
RESEARCH
COUNCIL

Centre for the Study of Globalisation and Regionalisation (CSGR), University of Warwick, Coventry CV4 7AL, United-Kingdom. URL: http://www.warwick.ac.uk/fac/soc/CSGR 


\title{
Textiles Beyond the MFA Phase-Out
}

Dean Spinanger

Kiel Institute of World Economics

CSGR Working Paper No. 13/98

July 1998

\begin{abstract}
:
The Uruguay Round (UR) Agreement on Textiles and Clothing (ATC), which was meant to undo the MFA, is to be effected by the year 2005 despite inherent tendencies in the past to continually protect textile and clothing (T\&C) industries? How did we get into this protectionist quagmire? What lay behind being able to sell protection in importing countries to $\mathrm{T} \& \mathrm{C}$ exporting countries? What pattern of $\mathrm{T} \& \mathrm{C}$ trade has hence evolved and what are the implications thereof? Based on this background the paper analyzes what currently influences where we now are four years after the UR ratification. Aside from tariffs and non-tariff barriers, major influences include regional trade agreements, changing locational demands, normal development trends and shifting factor intensities of production. It is then cautiously concluded that, despite backloading liberalization and factors which increase the pressure from major T\&C exporting countries, the wrapping up of the ATC by Jan. 1st., 2005, will be basically abided by, even if it is accompanied by some sidestepping and perhaps postponements.
\end{abstract}

Keywords: ATC, MFA, WTO, TEXTILES, CLOTHING, LIBERALIZATION, PROTECTION, QUOTAS, URUGUAY ROUND.

Address for correspondence:

Dean Spinanger

Kiel Institute of World Economics

24100 Kiel, Germany

Tel./Fax (+49) 431 8814-207/-500

E-mail: dspinanger@ifw.uni-kiel.de 


\section{Contents}

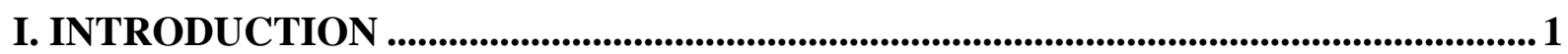

II. SOME BACKGROUND.........................................................................................................2

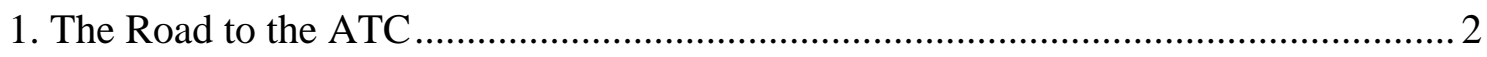

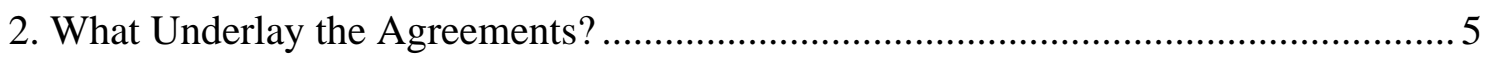

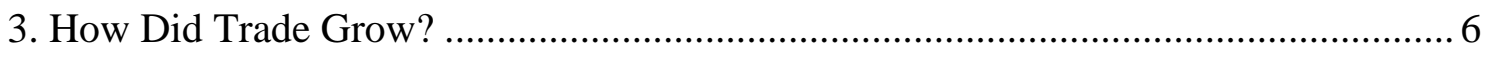

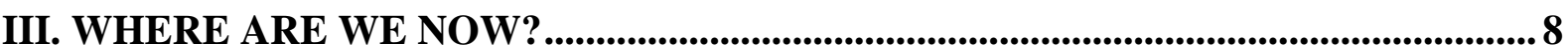

IV. BEYOND THE MFA PHASE-OUT - A CRYSTAL BALL ATTEMPT ....................13

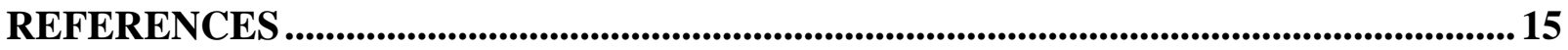

\section{List of Tables}

Table 1 - Some Key Dates in the History of Establishing the MFA and the ATC …….....................

Table 2 - Textile and Clothing Exports of Selected ICs and DCs: 1965-1996 .................................ii

Table 3 - Structure of and Shifts among Leading Textile and Clothing Exporters: 1965-96 ...........iii

Table 4 - Exports of Primary Textile Inputs, Textile and Clothing Products: Values, Shares and Growth Rates 1980-1994 ..................................................................................................... iv

Table 5 - Trade in Total Manufactures, Textiles and Clothing as Percentage of Apparent Consumption in the EU, United States-Canada and Japan: 1980-1994 ............................. v

Table 6 - Overview of Computable General Equilibrium Assessments of the Uruguay Round Sectoral Distribution of Welfare Effects .......................................................................... vi

Table 7 - Tariff Concessions Given and Received: Post Uruguay Round Tariff Rates and Percent Reductions by Selected Countries....................................................................................vii

Table 8 - Imports of Clothing Products for Selected OECD Countries by Major Suppliers: 19901996 


\section{List of Diagrams}

Diagram 1 - Tariff Rates for Textile and Clothing Products before and after Uruguay Round (UR) by Regions/Countries................................................................................. ix

Diagram 2 - Tariff Rates for Textile and Clothing Products before and after Uruguay Round (UR) by Regions/Countries.......................................................................................

Diagram 3 - Per Capita Clothing Imports (US\$): Total and from Non-ICs......................................... xi 
"And Jehovah God made for Adam and his wife coats of skins, and clothed them" (Holy Bible, Genesis: 3:22)

\section{TEXTILES BEYOND THE MFA PHASE-OUT}

\section{INTRODUCTION}

Can perhaps the almost never-ending demand for protecting domestic textile and clothing (T\&C) industries trace its roots back to a monopolist at our genesis? As understandable as such thoughts may be in light of the tenacity with which protectionism still permeates this sector across almost all countries, it has yet to be verified that such a constellation belongs to those factors given to us as natural resources indigenous to this planet. We are rather indubitably dealing with a fundamental offshoot of political economy intertwined with the basic necessity of human beings to be clothed - just as basic as the need to seek food to exist or shelter as protection from the elements. Can it thus really be surprising to determine that the edicts of an anonymous international organization located somewhere beyond mountains surrounding a small country in Europe - call it GATT or WTO - encounter noticeable resistance in trying to inject transparency, consistency and openness into trade relations between different economies in this world? The result of this resistance is backsliding on, or sidestepping of agreed-upon liberalization measures or frontloading protection.

Since in the past the above has often proven to be the fate of liberalization measures applied to $\mathrm{T} \& \mathrm{C}$ products, the obvious question arises in the context of the topic implicitly assigned to me: How will protection continue to live on after the UR agreements have been effected? But perhaps the question should be worded otherwise: How can the UR agreements be effected despite the seemingly inherent tendencies to protect $\mathrm{T} \& \mathrm{C}$ industries? The task of this paper, after outlining where we have come from, what lay behind the arrangements and how trade flowed, is to highlight what is happening in the world to promote or hinder the true integration of an industry that like few others has contributed to developing the wealth of nations. It concludes with an attempt to look into the crystal ball and predict what the future holds beyond the MFA phase-out. 


\section{SOME BACKGROUND}

\section{The Road to the ATC}

The road leading to the MFA, then to its subsequent extensions and finally to its agreed-upon phase-out in the context of the ATC by the year 2005, has often been described and analyzed as well as its impact thoroughly investigated. ${ }^{1}$ It suffices for this paper to merely broad-brush some 50 years of restrictions on T\&C trade, which (after WW II) began in the second half of the 50's, with Japan being pressured by the US into imposing "voluntary export restraints" on cotton textiles (see Table 1). These were followed by "voluntary restrictions" (likewise on cotton textile products) being placed by the United Kingdom first on Hong Kong then on India and Pakistan. Under the auspices of GATT, which had already paved the way for measures dealing with market disruptions (see below), the Short Term Arrangement (STA) was agreed-upon in July of 1961 only to be replaced with the Long Term Arrangement (LTA) in February of 1962). ${ }^{2}$

However, in the course of the 60 's ${ }^{3}$ and particularly into the early 70 's, as numerous Asian countries began to develop their textile and clothing industries, it become quite obvious to the respective governments in importing countries that it was "necessary" to design a more all encompassing package of restraints. This was deemed essential to effectively regulate the rapidly expanding spectrum of T\&C products emerging from the DCs and "threatening" the

1 The reader is referred to the following sources, as well as additional worthwhile references therein: GATT (1972); Keesing, Wolf (1980); GATT (1984); Aggarwal (1985); Silberston (1989); Hamilton, ed. (1990); Trela, Whalley (1990); Navaretti, Faini, Silberston, eds. (1995); Finger, Harrison (1996); Yang, Martin, Yanagishima (1997); Baugham, Mirus, Morkre, Spinanger (1997).

2 It is worthwhile noting that at this point in time the US import penetration ratio for textiles was about $6 \%$, and for clothing around $2 \%$. That these low levels could trigger such a massive response is perhaps surprising, but indicative of the $\mathrm{T} \& \mathrm{C}$ sector (see Introduction).

3 In the early 60 's Hong Kong accounted for almost $80 \%$ of all non-ICs exports of clothing products from developing countries. 
T\&C industries in ICs. ${ }^{4}$ The growth rates of DCs in the period 1965-1973 speak for themselves. ${ }^{5}$ The ensuing negotiations, which went down to the wire, gave birth to the MFA, designated to come into being as of 1 January 1974. While it and its successors up to the completion of the UR agreements contained wording which underlined the short-term nature of the agreement to permit structural adjustment in the ICs (see footnote 4), the short-term nature had by no means become apparent by the end of the 80 's. What had become apparent, however, was that the entire setup had become so complex that there seemed to be almost no other reasonable solution than to phase-out the MFA in the course of the UR. Hence, the birth of the ATC.

The agreed-upon solution in the form of the ATC set down the following basic framework:

- the MFA is to be phased out in four tranches over a 10 year period (1/1/1995; 1/1/1998; $1 / 1 / 2002 ; 1 / 1 / 2005)$, encompassing $16 \%, 17 \%, 18 \%$ and $49 \%$ of imports of all specified T\&C products based on volumes in the year 1990;

- products not liberalized, but under quota or elsewise restrained will have their growth rates increased during the first three steps of phase-out period by $16 \%, 25 \%$ and $27 \%$ respectively;

4 The position of the EEC was stated as follows: "The common commercial policy pursues the twofold objective of progressive liberalization of trade, ... while avoiding any market disruption in the Community. ... The maintenance by the Community of certain restrictions on international trade in textiles and clothing is primarily attributable to the fact that, ... the Community cannot eliminate these restrictions as long as the conditions of competition prevailing in world trade remain abnormal ... while healthy competition no doubt plays an essential incentive role in the adjustment of enterprises ... it is likewise true that excessive pressure on selling prices, because of imports [at abnormally low prices] can jeopardize any adjustment that is in progress..." (GATT 1972: VII-39). It is very much worthwhile to compare these words with a situation in the Zollverein some 130 years earlier when Bavarian and Württemberg yarn producers complained about unfair competition with Prussian producers (Henderson 1959: 183-184): "At the Stuttgart General Congress of 1842 Bavaria and Württemberg demanded increased import duties on both cotton and linen yarn. Prussia objected and ... complained [to the Zollverein about] the attitude of the South German protectionists. The note criticised the South German cotton spinners for their persistent selfish clamour for assistance and their disregard for the interests of other industries and of consumers [italics by author]".

5 That China's exports grew at a relatively low rate during this period of time is due to the fact that it had yet to open up its economy. 
- each of the four groups, into which the entire spectrum of textile products had been broken down (i.e. tops/yarns, fabrics, made-ups and clothing), must be included in each of the liberalization tranches during the 10 year period. In the case of the EU the volume of total ATC imports in the base year 1990 consisted of $37 \%$ tops and yarns, $22 \%$ fabrics, $24 \%$ made-ups and $17 \%$ clothing;

- the liberalization process for members is binding and final.

And finally, it could have been concluded that the negotiating parties were indeed serious in effectively dismantling the MFA, as in Article 7, para. 1 of the ATC (GATT 1994) the word "promote" had been replaced with the more forceful word "achieve".

As successful as the countries were in achieving an agreement on $T \& C$ products, they were just as unsuccessful in structuring it in a manner which would have effectively brought $\mathrm{T} \& \mathrm{C}$ products under the jurisdiction of the GATT framework throughout the phase-out period. It was indeed a masterpiece of watering down and postponing. It watered down the liberalization process by including a far wider range of $\mathrm{T} \& \mathrm{C}$ products in the population of products to be liberalized than was ever included to begin with. It postponed any significant liberalization until the final liberalization tranche as of $1 / 1 / 2005$, at which time - as it stands now - the most sensitive products will be subjected to basic GATT principles. The sham result is best represented by simply noting that - believe or not - tire cords, tampons and tents were products liberalized by Canada, the EU and the USA in the first liberalization tranche as of 1/1/1995 (see Baughman et al. (1997) in this context).

It can thus hardly be surprising that in the preparations for the December, 1996, Singapore WTO Ministerial, developing countries (i.e. major exporters) virtually threatened to allow the Ministerial to collapse, if significant changes were not effected to force a structure of liberalization which would reduce the probability of an impasse in the year 2005 when the remaining $49 \%$ of $\mathrm{T} \& \mathrm{C}$ products have to be liberalized. That the situation was critical is underlined by the comment made by the WTO's Council for Trade in Goods, an institution not known for being overly frank (1996: para. 16.4): "The first stage integration had ... not meaningfully improved access to these markets [i.e. basically those of the US, Canada and the 
EU]. There were no indications that the second stage integrations ... would be more commercially meaningful."6

The initiative on part of the T\&C exporting countries to have the ATC effectively eliminate NTBs over the course of the ATC, and not just in the final tranche, proved to be unsuccessful, aside from being able to have stronger wording introduced into the final communiqué. One reason for this was the attempt by some ICs (in particular the US) to have social and labor standards to be included in the WTO's brief. Hence, the mere inclusion of stronger wording concerning the ATC could be considered to be the price paid for keeping the WTO's involvement with social and labor standards limited to cooperation with the ILO. The question about whether it will remain at this level is an open question. But is it more open than the question about whether the ATC will be carried out as agreed upon?

\section{What Underlay the Agreements?}

Whether $\mathrm{T} \& \mathrm{C}$ products over the last four decades have been subjected to much higher protection than other internationally traded goods or not, is an important question, but - as far as the MFA is concerned - not the key point. The core issue is that T\&C products were exempted from basic GATT principles, because of a "dirty deal" struck between importing and exporting countries. It was a "dirty deal" because it was cut outside the GATT legal framework by "selling" to exporting countries the right to continue to export given amounts of $\mathrm{T} \& \mathrm{C}$ products to importing, that is industrialized countries. The selling point was simple and to the point: The exporting countries had the opportunity to capture the rents ensuing from restricting supplies.

There was a flip side, of course, namely that the exporting countries had to accept the quantitative limits dictated to them. These were basically founded on the past performance of the countries concerned. Naturally such a procedure of using past performance implanted

6 In the Report of the Textiles Monitoring Board (TMB) it was worded more drastically (WTO G/L/113, A.16): "... should the pattern of selection of products to be integrated in the second and third stages ... reproduce that of the first stage, the implementation of the integration [of T\&C products] on 1 January 2005 ... would prove difficult." 
seeds of discontent for those not initially members and would spawn problems along the way. It was also "dirty" because it was carried out under the veil of being but temporary, that is, just long enough to permit the necessary structural adjustment to occur in the industrialized countries (ICs). In essence, however, the restraints proved to be relatively perpetual, as the agreed-upon growth rates of quotas for competitive exporters proved to be lower than demand, and thus quota utilization rates remained relatively high over a long period of time. And it was even "dirtier" in light of what could not have been fully realized at that time, namely that the purveyors of the deal maintained the option to apply contingent protection measures (e.g. anti-dumping proceedings) if imports grew too fast. ${ }^{7}$ But this is in essence the heart of the protectionism that underlay the MFA and may well underlie its phase-out. Generally speaking, the following reaction pattern can be contended to hold: As the need for additional protection is perceived, so are ways and means found to carry this out. 8

\section{How Did Trade Grow?}

And how has the flow of world trade in T\&C products developed over the last 30 years Table 2 provides a starting point. It contains data on the 13 largest T\&C exporters in 1996 and traces their performance back to the mid 60's or rather to the beginning of the MFA (i.e. 1973). ${ }^{9}$ It reveals that - on the whole - the shares of these listed countries in world T\&C trade have tended to slowly decrease over the years. Thereby, however, the picture is quite different in the case of textiles than in the case of clothing. As far as textiles are concerned, the

7 As noted by Raffaelli and Jenkins (1995: 1-3), the initial legalese construction for launching NTBs on T\&C products (i.e. the STA, the LTA and MFA) came from work by the GATT Contracting Parties on market disruption. It thus borders on double jeopardy if, at a later point in time, contingent measures are applied to $\mathrm{T} \& \mathrm{C}$ imports which have already been limited by NTBs.

8 This runs analogous to Parkinson's law (1958: 9), by which "work expands so as to fill the time available for its completion".

9 If the 13 largest exporters of T\&C products in 1965 had been used as a set it would have included the Netherlands (1965: 9; 1996: 16), Switzerland (1965: 12; 1996: 25) and Austria (1965: 13; 1996: 22). Their inclusion (and the exclusion of Korea, Taiwan and Turkey) would have caused the sum in 1965 to be higher by 8.8 percentage points and the sum in 1996 to be lower by 9.1 percentage points. 
countries listed have virtually held their own since 1973, dropping just one percentage point in the 23 year period since the MFA was enacted. In the case of clothing it clearly reveals that the listed countries have been continually losing shares to other non-listed, primarily developing countries.

Breaking down these trends into IC and DC groups (see Table 3) yields a more differentiated picture.

Textiles: In the 20 years since the MFA was established the ICs lost as much on market shares as the listed DCs gained (ICs: -17.7 percentage pts.; DCs: +16.7 percentage pts.). In other words: a reallocation took place between the listed countries or rather, other countries were not successful in capturing market shares.

Clothing: Major shifts took place between ICs and DCs as well as between those countries listed and those not listed. Whereas the ICs had a 50\% higher share in 1973 than DCs (or a 300\% higher share in 1965), by 1983 they had fallen $20 \%$ below DCs. However, the real winners over the last 20 years were the other, primarily developing countries, which increased their share by almost 15 percentage points since the MFA was effected.

The above trends are also accordingly reflected in the structure of exports of specific $\mathrm{T} \& \mathrm{C}$ product groups (Table 4). Knowing that some of the most capital intensive processes in the $\mathrm{T} \& \mathrm{C}$ industry can be found in the manufacturing of primary textile inputs as well as certain textiles, while the most labor intensive are concentrated in the making clothes, the respective differentiated shifts of production away from ICs to DCs can be seen. It is quite evident that the inroads made by DCs in all areas is substantiated - a trend which can be further documented when the flows of textile machinery are examined. DCs are now by far the largest importers of T\&C machinery - a good dozen years ago it was quite different. And DCs use the imported textile machinery from ICs to produce the world-quality inputs for the export- 
oriented clothing industry, which are then shipped to ICs. ${ }^{10}$ There the DCs have been able to almost double their shares in apparent consumption over the decade 1985-1994 (or almost triple then in the period 1980-1994) as can be seen in Table 5. However, inroads by DCs into the apparent consumption of textiles in ICs have tended to be lower than in the case of total manufactures.

\section{WHERE ARE We NoW?}

All the above mentioned developments in the flows of $\mathrm{T} \& \mathrm{C}$ products have brought us to where we are today almost four years after the conclusion of the Uruguay Round. They reflect numerous influences, that is the impact of

- the MFA and tariff barriers on T\&C products,

- regional trade agreements,

- changing locational demands,

- normal development trends and

- shifting factor intensities of production.

Let us start with the impact of the MFA with its tariff and non-tariff barriers. ${ }^{11}$

10 It can be shown that it is an essential ingredient in a successful T\&C export strategy vis-à-vis aiming at IC markets to use machinery which produces output up to world-market standards. To date such machinery stems almost entirely from ICs. To the extent that such textiles are not produced domestically to world market standards at competitive prices, the other option is to import them. This is the path that Bangladesh successfully followed over the last 15 years (see Spinanger, 1987), and basically reflects the philosophy of Hongkong over the course of its development path.

11 The author realizes that completely differentiating between the various factors is not quite possible, but still intends to use this breakdown as an attempt to illustrate the influence of the various factors. 
As far as analyzing the impact of UR is concerned, there is no product group which produce world welfare increases to the extent that the elimination of MFA is posited as doing (see Table 6). Based on an average of CGE estimates made around the end of the UR, liberalizing the area of $\mathrm{T} \& \mathrm{C}$ products accounted for almost $40 \%$ of the welfare gains calculated from liberalization measures agreed-upon in the UR. This is an impressive number and one which could be used as a verification of the importance of such multilateral trade negotiations.

Unfortunately, a caveat needs to be injected here, as the CGE models used so far fail to take into account some crucial aspects of the MFA:

- First of all, the quota rents applied in the models and accruing to exporting countries, ${ }^{12}$ reflect the world as it was in the 1980's, in particular the world as it was in Hong Kong. Times have changed and quota rents in Hong Kong - as well as in other countries - have been decreasing sharply and even approaching zero in many cases. In other words, one of the major factors attributed to decreasing the world's welfare seem to be disappearing. One key reason behind this is the shift in demand away from large Asian suppliers to exporters closer to home markets (see below).

Secondly, economies like Hong Kong, South Korea and Tawan have long since become involved in producing many of those $\mathrm{T} \& \mathrm{C}$ products offshore, which they used to manufacture domestically. In doing so they are still taking advantage of quota rents, but doing this abroad, that is, of course, to the degree they still exist. The CGE models' calculations of welfare gains do not allow for the flow of capital assets and/or human capital from Hong Kong (or Taiwan or ...) to a third country (e.g. Thailand, Mauritius ...). Perhaps more importantly, they do not allow for the transfer back to Hong Kong of rents accruing to this capital. Hence, at least, the distribution if not the size of the welfare gains and regional disaggregation are not correctly taken in consideration. In such cases it may not just be the regional distribution of welfare gains, but - perhaps even more important - the more productive use of capital and human resources in other countries. All in all, the published CGE calculations of welfare increases

12 It must of course also be questioned as to whether quota rents are entirely usurped by exporting countries. In the meantime, namely, it has been posited that large retail organizations from IC's can use their buying power to extract sizeable shares of the quota rents (see Krishna, Tan, 1997). 
from an elimination of the MFA may well be misspecified, and particularly overestimated to the extent that quota rents have not been correctly adjusted to levels prevailing at the start of the ATC or rather to current levels.

As far as the UR tariffs are concerned, across the board the tariffs on T\&C products remain the highest, except for the agriculture sector (see Table 7). They vary between 3-5 times the value of tariffs for all industrial goods in the ICs. Their percent reduction, however, ranks as one of the lowest among the product categories - a sure sign of the sensitivity of this sector to liberalization. As can be seen in Diagrams 1 and 2, the clothing products were - generally speaking - subjected to smaller tariff changes than textile products. Only in the case of the EFTA countries and Japan (Diagram 1) were the reductions in clothing products almost in line with the reductions in textile products. It also becomes quite apparent that the DCs still have to decrease tariffs considerably in order to truly improve market access. Since relative tariff rates did not change all that much, trade in $\mathrm{T} \& \mathrm{C}$ products was probably not noticeably affected.

A major impact on trade flows ensues from the establishment of regional integration schemes (including offshore processing legislation) together with changing locational demands dictated by just-in-time policies and ever-faster fashion cycles. In the case of the EU, these were already having a far more profound effect on Europe's economic landscape than the ongoing initial implementation of the UR agreements. Specifically, the completion of the single market in the EU as of January 1, 1993, the expansion of the EU from 12 to 15 members as of January 1, 1995, and the attempts to integrate the Central and Eastern European economies, all had prompted $\mathrm{T} \& \mathrm{C}$ industries throughout Europe to more rapidly rethink corporate strategies. Given the importance of minimizing the economic distance between locations of production and consumption in such a time-conscious sector as the fashion industry, just-intime production, rapid reordering and quick fashion response were all obviously easier to achieve with countries next door than with producers far away in Asia. On the other side of the Atlantic came the implications of the NAFTA, which likewise was shifting demand away from suppliers of $\mathrm{T} \& \mathrm{C}$ products in Asia. In both cases it was also the existence of offshore processing legislation, which enabled firms to circumvent MFA quotas and helped induce 
them to establish more than just arm's length production platforms in (almost) neighboring countries.

All these trends can easily be seen in Table 8 which portrays the country structure of clothing imports for Germany, United Kingdom, Italy and Sweden. In the case of the four EU countries, the Asian countries, in particular the East-Asian countries, have been loosing out to the Euro-Med countries since around 1993 (see table for definition of country groupings), whereby Germany and Italy imported more from Euro-Med by 1996 (or earlier) than from Asia or the EU. Sweden, after very rapidly expanding imports from Asia - especially EastAsia - through 1994 (its share increased by over 55\% from 1990-1994), tapped to an ever greater degree East-European countries (their share jumped over 25\% in the period 19941996). The pattern in the US was similar vis-à-vis Latin America; with its share virtually doubling over the seven year period, accounting for almost all of the decrease in the share of imports from Asia.

The impact of the normal development trends can be best described as a growing up process, in which countries switch into more physical-capital or human-capital intensive areas of production as their income levels increase. To some degree this was already seen in Table 2, where countries like Korea and Taiwan shifted out of the labor-intensive production of clothing in the early 80's and have in the meantime concentrated on the capital-intensive production of textiles. It becomes particularly evident in the ever-increasing share of those countries which were not among the top 13, but had become in the course of the years ever more adept at efficiently producing clothing. Of course, some of this increase in the value of exports must be attributed to the MFA itself, as countries still maintained production activities, but with higher value added shares particularly in order to capture rent from the quotas they held. It might thus be contended that it was to a notable degree that the MFA hindered countries from following an efficient development path. That is, it kept valuable productive resources flowing into the $\mathrm{T} \& \mathrm{C}$ industries long after they should have been flowing into more efficient production areas.

The differing capital intensities of production between the $\mathrm{T} \& \mathrm{C}$ industries has been one factor which has driven trade flows in $\mathrm{T} \& \mathrm{C}$ products. But it also has been the MFA which has influenced this trend. Especially in the production of textile products have major advances in 
technology been achieved which have helped maintain textile production in ICs. While sewing together pieces of fabric to produce a shirt is extremely labor intensive - and will continue to be so in the coming years - parts of the textile industry have become some of the most capital intensive processes in the manufacturing industry. The result of these developments could be seen in Table 4, where the ICs in the upstream areas of production were able to able to perform relatively better. These wide differences in capital intensities between the textile and clothing industries also helps to explain why - given the possibility of efficiently carrying out various stages of production in different locations - it has become worthwhile for countries like Germany, Italy and the USA to produce the capital-intensive inputs and then have them turned into clothes just east or south of the border.

But even here the constellation may change once NTBs are removed, as it is quite likely that it was the MFA which kept major European producers of high-quality textile inputs from establishing large spinning and fabric manufacturing facilities in those countries with high productivity and low labor costs, namely in Asia. After all, the European companies could not be sure that such facilities would be able to produce at adequate capacity levels, given the existence of quotas. However, since quotas are now in the process of being eliminated it is quite possible - and there are indications that this is indeed occurring - that these producers will be investing in this part of the world.

But there is also another issue, which affects the production of the machines themselves. In the past these have been almost entirely produced in ICs (almost 90\%), with Germany, Japan, Italy and Switzerland accounting for the lion's share. Here the interface with the local textile and clothing industry proved to be an essential ingredient in producing ever better, ever more efficient machines, as the actual testing of the machines could be carried out at a textile manufacturing company virtually around the corner. This interface between the textile machine industry and the textile industry plays an important role from which both parties profited. It was not only the synergetic effect stemming from approaching the problem from different angles, it was also the ability to test machines under true working conditions before they came on the market (for a theoretical treatment of this issue see Harhoff [1991]). But now, with ever larger shares of the $\mathrm{T} \& \mathrm{C}$ complex being located in DCs, textile machinery companies have begun to establish production facilities in DCs, which do not just merely 
assemble imported parts of textile machines, but actually engage in testing the machines in situ. Furthermore, and no doubt even more important, the companies are creating machines more adapted to conditions in DCs, so they can be more efficiently utilized. ${ }^{13}$ Hence the shifting of the T\&C industry to DCs is also leading to a shifting of the T\&C machinery industry to the same countries (e.g. India, China, Indonesia and Brazil). But this shifting will only apply to parts of the industry as there are still other reasons to maintain research and production facilities in ICs (e.g. the productive interface between the industry and technical universities).

\section{BEYOND THE MFA PHASE-OUT - A CRYSTAL BALL ATTEMPT}

In summarizing the above for beyond the MFA phase-out I can only come to the conclusion that the crystal ball is clouded. Nonetheless, as Michael Evans used to say: "Often wrong, but never in doubt."

The good news: There are signs out there which seem to be pointing to or at least supporting a successful conclusion to phasing out the MFA and returning to international trade in textiles and clothing determined by traditional division of labor factors. For instance, Norway and Canada have recently opted out of certain restraints on T\&C products. This could perhaps induce other countries to do the same. The above mentioned $\mathrm{T} \& \mathrm{C}$ machinery industry as well as the textile industry itself have created joint interests which could possibly lead them to supporting a complete integration so they themselves can remain competitive. And on top of this, the Asian crisis may very well prove to be a blessing in disguise for the phase-out of the MFA: It may place restraints on importing countries trying to back out of the ATC agreements

13 One area where this is leading to major changes concerns dying and finishing machines. These machines in ICs are calibrated to run under conditions which hardly leave a trace of pollutants in the environment and thus are extremely expensive. In DCs, however, environmental standards are not quite as stringent and thus the machines can be offered at considerably lower prices. This is not saying that the textile machinery producers are condoning the pollution of the environment in DCs. But rather that in some European countries the degree to which the environment is protected may well have exceeded an economically "sensible" level. 
by denying access to countries trying to improve their economic situation in line with assistance and advice received from international organizations.

The bad news: The Asia crisis could very well make exports from these countries so inexpensive (i.e. sold at "dumping prices") that ICs apply more contingent protection measures. Furthermore, the bias injected into international trade with $T \& C$ products by setting up regional integration schemes works against a global division of labor. This could be seen in particular in the case of Sweden after it joined the EU. That the EU also opted out of certain restrictions vis-à-vis bordering countries only strengthens this contention. The US in its latest attempt to maintain protection despite the ATC by "forcing" Turkey to agree to new restrictions is perhaps only the beginning of an increased use of such contingent protection. Likewise, the EU doesn't seem to be able to restrain itself from applying anti-dumping duties to greige textiles, even though it rejected this action earlier - France and the Southern alliance seem to be be determined to push this through. They do not evidently realize that one of the most competitive industries in the $\mathrm{T} \& \mathrm{C}$ complex, namely the dying and finishing sector, will be damaged by these actions.

To conclude: If we can make it past the millennium bug, maybe we can make it past January $1^{\text {st }}, 2005$. It won't be without glitches and maybe some side stepping, as well as a little postponing also, but given the trends in trade (see Diagram 3) the pressure to relent rather than stonewalling may just be too large. Let us hope so. 


\section{REFERENCES}

Aggarwal, Vinod K. (1985). Liberal Protectionism - the International Politics of Organized Textile Trade. Berkeley.

Baughman, Laura, Rolf Mirus, Morris Morkre, Dean Spinanger (1997). "Of Tyre Cords, Ties and Tents - Window-Dressing in the ATC." The World Economy 20 (4): 407-434.

Finger, J. Michael, Ann Harrison (1996). "The MFA Paradox: More Protection and More Trade?" In: Krueger, Anne O. (ed.), The Political Economy of American Trade Policy: 197-254. Chicago.

Finger, J. Michael., Merlinda D. Inges, Ulrich Reincke (1996). The Uruguay Round Statistics on Tariff Concessions Given and Received. Washington, D.C.: The World Bank.

Francois, Joseph F. (1995). Assessing the Uruguay Round. In: Martin, Will and L.Alan Winters (eds.), The Uruguay Round and the Developing Countries. World Bank, Washington, D.C. World Bank Discussion Papers 307: 117-214.

Francois, Joseph F. (1996). A User's Guide to Uruguay Round Assessments. WTO Staff Working Paper RD-96-003. London.

GATT (1972). Study on Textiles (L3797, Add. 1, Add.2). Geneva.

GATT (1984). Textiles and Clothing in the World Economy. Geneva.

Hamilton, Carl B. (ed.;1990; ). Textile Trade and the Developing Countries - Eliminating the Multi-Fibre Arrangement in the 1990s. Washington, D.C.

Harrison, Glenn W., Thomas F. Rutherford and David G. Tarr (1995). Quantifying the Uruguay Round. In: Martin, Will and L.Alan Winters (eds.), The Uruguay Round and the Developing Economies. World Bank Discussion Paper 307. Washington, D.C.

Henderson, William O. (1959). The Zollverein. London.

Harhoff, Dietmar (1991). R\&D Incentives and Spillovers in a Two Industry Model. Zetrum fuer Europaeische Wirtschaftsforschung GmBH, Discussion Paper No. 91-06, Mannheim.

Hertel, Thomas W., Will Martin, Koji Yanagishima, Bettina Dimaranan (1995). Liberalizing Manufactures in a Changing World Economy. In: Martin, Will and L.Alan Winters (eds.), The Uruguay Round and the Developing Economies. World Bank Discussion Paper 307. Washington, D.C.

Keesing, Donald B., Martin Wolf (1980). Textile Quota against Developing Countries. Thames Essay 23. London. 
Krishna, Kala, Ling Hio Tan (1997). The Multifibre Arrangement in Practice: Challenging the Competitive Framework. In: Robertson, David (ed.)., East Asian Trade after the Uruguay Round: 59-77. Cambridge.

Navaretti, Giorgio Barba, Riccardo Faini, Aubrey Silberston (eds.;1995). Beyond the Multifibre Arrangement? Third World Competition and Restructuring Europe's Textile Industry. OECD, Paris.

Nguyen, Trien T., Carlo Perroni and Randall M. Wigle (1993). An Evaluation of the Draft Final Act of the Uruguay Round. The Economic Journal 103 (November): 1540-1549.

Parkinson, C. Northcote (1958). Parkinson's Law or the Pursuit of Progress. London.

Raffaelli, Marcelo and Tripti Jenkins (1995). The Drafting History of the Agreement on Textiles and Clothing. ITCB, Geneva.

Silberston, Aubrey (1989). The Future of the Multi-Fibre Agreement - Implications for the UK Economy. HMSO, London.

Spinanger, Dean (1987) "Will the Multi-fibre Arrangement Keep Bangladesh Humble? The World Economy, March: 75-84.

Trela, Irene, John Whalley (1990). "Global Effects of Developed Country Trade Restrictions on Textiles and Apparel." The Economic Journal 100 (403): 1190-1205.

UNCTAD (1991, 1997). Handbook of International Trade and Development Statistics. New York.

WTO (1997). Annual Report, Vol. II. Geneva.

Yang, Yongzheng (1994). Trade Liberalization and Externalities: A General Equilibrium Assessment of the Uruguay Round. Mimeo. Australian National University.

Yang, Yongzheng, Will Martin, Koji Yanagishima (1997). Evaluating the Benefits of Abolishing the MFA in the Uruguay Round Package. In: Hertel, Thomas (ed.), Global Trade Analysis: 253-279. Cambridge. 
Table 1 - Some Key Dates in the History of Establishing the MFA and the ATC

\begin{tabular}{|c|c|}
\hline Date & Action taken \\
\hline December, 1955 & $\begin{array}{l}\text { Japan (MITI) unilaterally restrains exports of cotton fabrics and clothing to USA "to } \\
\text { promote mutually beneficial relations". }\end{array}$ \\
\hline January, 1957 & Five year agreement reached with Japan on limiting overall textile exports to USA. \\
\hline November, 1958 & $\begin{array}{l}\text { United Kingdom signs "voluntary" limitation on cotton T\&C products with Hongkong, by } \\
\text { threatening otherwise imposition at lower volume levels. }\end{array}$ \\
\hline September, 1959 & United Kingdom signs similar restraint agreements with India and Pakistan. \\
\hline November, 1960 & $\begin{array}{l}\text { GATT Contracting Parties recognize the problem of "market disruption", even if it is just } \\
\text { threatened. }\end{array}$ \\
\hline July, 1961 & The Short Term Arrangement (STA) is agreed. \\
\hline February, 1962 & $\begin{array}{l}\text { The Long Term Arrangement (LTA) is agreed, to commence October 1, 1962, to last for } \\
\text { five years. }\end{array}$ \\
\hline $1963-64$ & The United States tries and fails to secure an international agreement on wool products. \\
\hline June, 1965 & $\begin{array}{l}\text { The United States tries and fails to negotiate restraints on Japanese exports of wool } \\
\text { products. }\end{array}$ \\
\hline June, 1966 & $\begin{array}{l}\text { The United Kingdom implements a global quota scheme in violation of the LTA - the LTA } \\
\text { providing only for product-specific restraints. }\end{array}$ \\
\hline April, 1967 & Agreement is reached to extend the LTA for three years. \\
\hline October, 1970 & $\begin{array}{l}\text { Agreement is reached to extend the LTA for three years. It was later extended three months } \\
\text { more, to fill the gap until the MFA came into effect. }\end{array}$ \\
\hline 1969-71 & United States negotiates VERs with Asian suppliers on wool and man-made fibers. \\
\hline December, 1973 & The MFA is agreed, to commence January 1,1974 , and to last for four years. \\
\hline July-December, 1977 & $\begin{array}{l}\text { The European Economic Community and the United States negotiate bilateral agreements } \\
\text { with developing countries prior to agreeing to extension of the MFA. }\end{array}$ \\
\hline December, 1977 & The MFA is extended for four years. \\
\hline December, 1981 & $\begin{array}{l}\text { The MFA is renewed for five years. The Reagan administration, under pressure from } \\
\text { increased imports resulting from dollar appreciation, negotiates tough quotas. }\end{array}$ \\
\hline July, 1991 & The MFA is extended pending outcome of the Uruguay Round negotiations. \\
\hline December, 1993 & $\begin{array}{l}\text { The Uruguay Round draft final act provides for a 10-year phase-out of all MFA and other } \\
\text { quotas on textiles in Agreement on Textiles and Clothing (ATC). }\end{array}$ \\
\hline January 1, 1995 & 1st ATC tranche liberalized by importing countries - $16 \%$ of 1990 import volume. \\
\hline January 1, 1998 & 2nd ATC tranche liberalized by importing countries - 17\% of 1990 import volume. \\
\hline January 1, 2002 & 3rd ATC tranche liberalized by importing countries - 18\% of 1990 import volume. \\
\hline January 1,2005 & 4th ATC tranche liberalized by importing countries $-49 \%$ of 1990 import volume. \\
\hline
\end{tabular}

Source: Based on Finger, Harrison (1996: Tab. 4.4) and Aggarwal (1985: 44-63). 
Table 2 - Textile and Clothing ${ }^{\mathrm{b}}$ Exports of Selected ICs and DCs: 1965-1996 (Shares ${ }^{\mathrm{c}}$, Rankings ${ }^{\mathrm{d}}$ and Growth Rates $^{\mathrm{e}}$ )

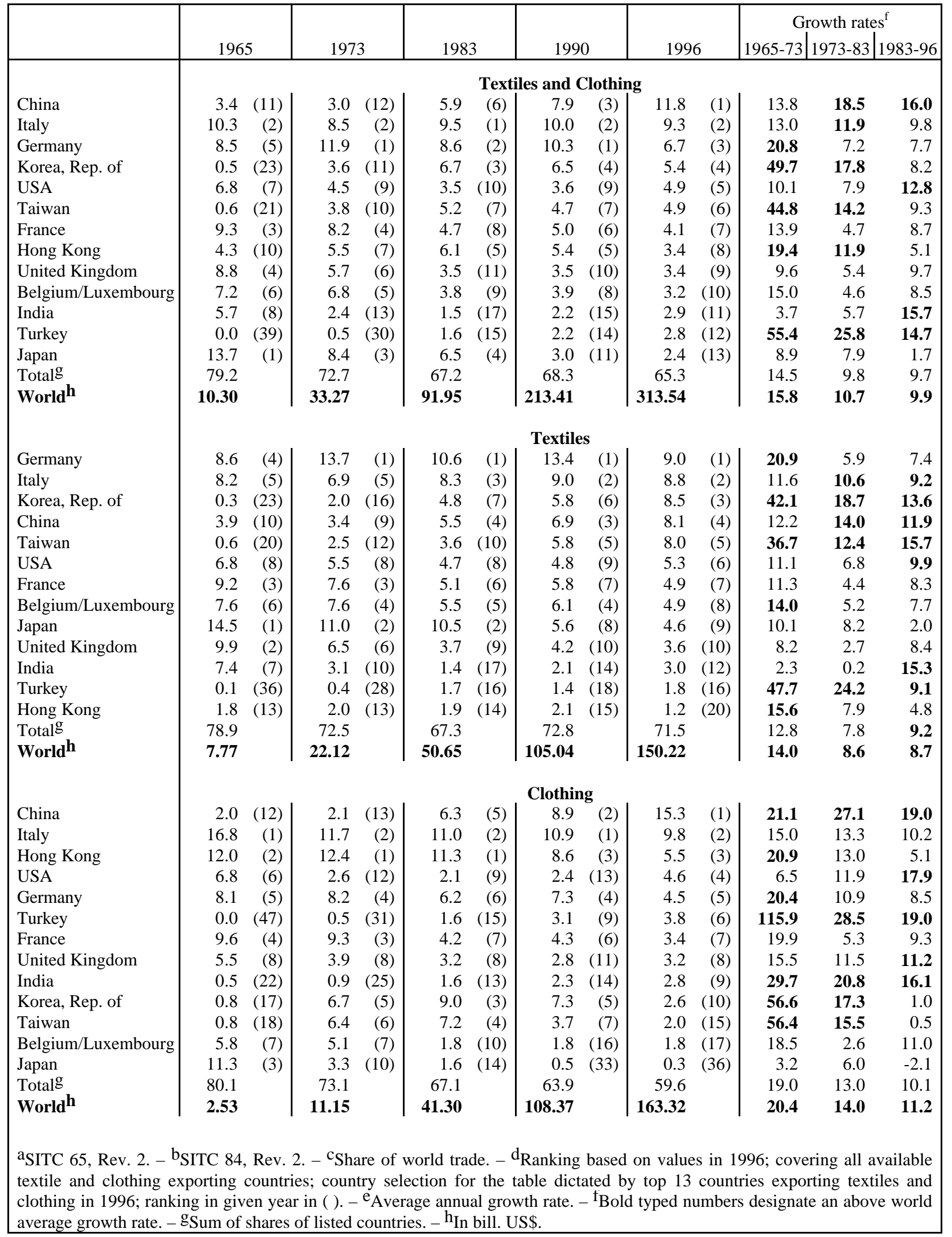

Source: Own calculations based on special UNCTAD tabulations and WTO (1997: Tab IV.56 and IV.63). 
Table 3 - Structure of and Shifts among Leading ${ }^{\mathrm{a}}$ Textile $^{\mathrm{b}}$ and Clothing ${ }^{\mathrm{c}}$ Exporters: 1965-96

\begin{tabular}{|c|c|c|c|c|c|c|c|c|}
\hline & \multicolumn{4}{|c|}{ Shares d } & \multicolumn{4}{|c|}{ Change in shares $\mathrm{e}$} \\
\hline & 1965 & 1973 & 1983 & 1996 & $65-73$ & $73-83$ & $83-96$ & $73-96$ \\
\hline & \multicolumn{8}{|c|}{ Textiles and Clothing } \\
\hline Total $^{f}$ & 79.2 & 72.7 & 67.2 & 65.3 & -6.5 & -5.5 & -1.9 & -7.4 \\
\hline $\mathrm{ICs} g$ & 64.6 & 54.0 & 40.1 & 34.0 & -10.6 & -13.9 & -6.1 & -20.0 \\
\hline \multirow[t]{2}{*}{$\mathrm{DCs}{ }^{\mathrm{h}}$} & 14.6 & 18.7 & 27.1 & 31.3 & +4.1 & +8.4 & +4.2 & +12.6 \\
\hline & \multicolumn{8}{|c|}{ Textiles } \\
\hline Totalf ${ }^{f}$ & 78.9 & 72.5 & 67.3 & 71.5 & -6.4 & -5.2 & +4.2 & -1.0 \\
\hline $\mathrm{ICs} g$ & 64.8 & 58.8 & 48.4 & 41.1 & -6.0 & -10.4 & -7.3 & -17.7 \\
\hline \multirow[t]{2}{*}{ DCsh } & 14.1 & 13.7 & 18.9 & 30.4 & -0.4 & +5.2 & +11.5 & +16.7 \\
\hline & \multicolumn{8}{|c|}{ Clothing } \\
\hline Total $^{f}$ & 80.1 & 73.1 & 67.1 & 59.6 & -7.0 & -6.0 & -7.5 & -13.5 \\
\hline $\mathrm{ICs} g$ & 63.9 & 44.1 & 30.1 & 27.6 & -19.8 & -14.0 & -2.5 & -16.5 \\
\hline DCs ${ }^{h}$ & 16.2 & 29.0 & 37.0 & 32.0 & +12.8 & +8.0 & -5.0 & +3.0 \\
\hline $\begin{array}{l}\text { aBased } \\
\text { Rev. } 2 . \\
\text { product } \\
\text { Table } 1 \\
\text { Table } 1\end{array}$ & $\begin{array}{l}13 \text { te } \\
\text { cent } \\
\text { bsol } \\
7 \text { ir }\end{array}$ & nd cl & $\exp$ & $\begin{array}{l}\text { count } \\
\text { y gro } \\
\text { hares. } \\
\text { in Ta }\end{array}$ & $\begin{array}{l}\text { n 199 } \\
\text { gs in } \\
\text { he to }\end{array}$ & $\begin{array}{l}\text { SITC } \\
\text { wor } \\
\text { expc } \\
\text { devel }\end{array}$ & $\begin{array}{l}\text { ev. } 2 \\
\text { orts }\end{array}$ & $\begin{array}{l}\text { ITC } 84 \\
\text { pective } \\
\text { sted in } \\
\text { isted in }\end{array}$ \\
\hline
\end{tabular}

Source: Own calculations based on sources in Table 1. 
Table 4 - Exports of Primary Textile Inputs ${ }^{\mathrm{a}}$, Textile ${ }^{\mathrm{b}}$ and Clothing ${ }^{\mathrm{c}}$ Products: Values, Shares and Growth Rates 1980-1994

\begin{tabular}{|c|c|c|c|c|c|c|c|c|c|c|}
\hline \multirow{3}{*}{$\begin{array}{l}\text { SITC } \\
\text { (Rev. 2) } \\
\text { group }\end{array}$} & \multirow[t]{3}{*}{ Products description ${ }^{\mathrm{d}}$} & \multicolumn{5}{|c|}{ Values $\mathrm{e}^{\mathrm{e}}$ and shares } & \multicolumn{4}{|c|}{ Growth rates $^{\mathrm{f}}$} \\
\hline & & \multicolumn{2}{|c|}{$1980-81$} & $1987-88$ & \multicolumn{2}{|c|}{ 1993-94 } & \multicolumn{2}{|c|}{ 80/81-87/88 } & \multicolumn{2}{|c|}{ 87/88-93-94 } \\
\hline & & \multicolumn{5}{|c|}{ World (\% IC) $)^{\mathrm{g}}$} & $\mathrm{ICs}$ & DCs & ICs & DCs \\
\hline & Total T\&C products & 104.06 & (64) & $176.00 \quad(56)$ & 272.82 & (46) & 5.8 & 10.9 & 4.1 & 11.3 \\
\hline & Primary textile inputs & 16.40 & (65) & $20.22 \quad(69)$ & 19.41 & $(58)$ & 3.5 & 2.2 & -3.1 & 3.4 \\
\hline 263 & Cotton & 7.67 & $(40)$ & $7.22 \quad(35)$ & 8.15 & (39) & -2.7 & 0.3 & 3.9 & 1.0 \\
\hline 268 & Wool (exc. tops), etc. & 4.50 & (84) & $7.20 \quad(86)$ & 4.73 & (76) & 7.3 & 5.0 & -8.7 & 2.0 \\
\hline 266 & Syn. fibres to spin & 2.97 & (89) & $3.95 \quad(80)$ & 4.58 & (60) & 2.6 & 13.3 & -2.3 & 15.0 \\
\hline \multirow[t]{2}{*}{267} & Other man-made fibres & 1.26 & (94) & $1.85 \quad(89)$ & 1.95 & (87) & 4.9 & 14.0 & 0.5 & 3.8 \\
\hline & Textile yarn, fabrics, etc. & 50.66 & (74) & $80.62 \quad(64)$ & 122.39 & (54) & 4.8 & 11.7 & 4.1 & 11.4 \\
\hline 653 & Woven man-n & 9.85 & (78) & $15.40 \quad(63)$ & 26.71 & $(48)$ & 3.4 & 14.9 & 4.8 & 16.0 \\
\hline 651 & Textile yarn & 13.50 & (77) & $20.67 \quad(68)$ & 25.47 & (56) & 4.0 & 13.1 & 0.2 & 9.2 \\
\hline 652 & Cotton fabrics, woven & 6.83 & (64) & $11.99 \quad(53)$ & 16.38 & $(48)$ & 5.5 & 12.6 & 3.6 & 7.1 \\
\hline 657 & Special textile fabr., prds. & 4.65 & $(85)$ & $8.09 \quad(82)$ & 14.36 & (69) & 7.7 & 11.1 & 6.9 & 20.4 \\
\hline 658 & Textile articles nes & 3.82 & (61) & $5.76 \quad(52)$ & 10.16 & (39) & 3.7 & 9.3 & 4.7 & 14.4 \\
\hline 659 & Floor coverings, etc. & 4.85 & (67) & $6.77 \quad(64)$ & 8.84 & $(62)$ & 4.2 & 6.2 & 4.0 & 5.5 \\
\hline 654 & Other woven text. fabr. & 3.35 & (72) & $6.16 \quad(68)$ & 8.56 & (71) & 8.2 & 11.1 & 6.4 & 3.9 \\
\hline 655 & Knitted etc. fabrics & 2.48 & (84) & $3.78 \quad(60)$ & 8.50 & (43) & 1.3 & 20.9 & 8.3 & 21.5 \\
\hline \multirow[t]{2}{*}{656} & Lace, ribbons, etc. & 1.33 & (84) & $2.00 \quad(72)$ & 3.41 & (60) & 3.7 & 15.0 & 6.1 & 15.9 \\
\hline & Clothing & 37.00 & (50) & $75.26 \quad(44)$ & 131.02 & (37) & 8.8 & 12.4 & 6.5 & 11.9 \\
\hline 843 & Fem. outerwear nonknit. & 8.59 & (53) & $18.59 \quad(47)$ & 33.17 & (37) & 9.8 & 13.6 & 5.8 & 13.4 \\
\hline 845 & Oute & 8.83 & $(56)$ & $19.53 \quad(46)$ & 28.74 & $(40)$ & 8.9 & 15.4 & 4.2 & 8.5 \\
\hline 842 & Mens outerwear notknit. & 7.88 & (48) & $12.84 \quad(45)$ & 24.01 & (36) & 6.3 & 8.1 & 6.9 & 13.8 \\
\hline 846 & Under garments knitted & 4.05 & (52) & $8.19 \quad(44)$ & 17.83 & (41) & 7.9 & 13.1 & 12.5 & 14.8 \\
\hline 844 & Under garments notknit. & 2.46 & (24) & $4.87 \quad(23)$ & 11.08 & (24) & 9.2 & 10.5 & 15.5 & 14.4 \\
\hline 848 & Headgear, nontext. clothing & 3.50 & $(51)$ & $7.81 \quad(39)$ & 10.65 & $(29)$ & 8.9 & 15.7 & 0.2 & 8.0 \\
\hline 847 & Textile clothing acces. nes. & 1.68 & $(65)$ & $3.43 \quad(59)$ & 5.54 & (54) & 9.2 & 13.3 & 6.8 & 10. \\
\hline
\end{tabular}

${ }^{a}$ SITC 26. - ${ }^{b}$ SITC $65 .-{ }^{c}$ SITC 84. - ${ }^{d_{\text {Ranked }}}$ within aggregates by 1993/94 values. - ${ }^{e_{B}}$ Bill. US\$, average of the two years. Based on UNCTAD (1991 and 1997) Tables 4.3.A and B. - f\%; average annual growth rates. Note: growth rates of individual groups calculated using raw data from Tables 4.3.A and B (UNCTAD 1991 and 1997). The bold typed figures represent above average growth rates for total T\&C products in the respective periods (i.e. average growth rates for 80/81-87/88: 7.8\%; 87/8893/94: 7.6\%). $-\mathrm{g} \%$ of world exports originating in ICs.

Source: Calculations based on UNCTAD (1991, 1997: Tables 4.3.A and B). 
Table 5 - Trade in Total Manufactures, Textiles and Clothing as Percentage of Apparent Consumption in the EU, United States-Canada and Japan: 1980-1994

\begin{tabular}{|c|c|c|c|c|c|c|c|c|c|c|c|c|}
\hline \multirow{4}{*}{ Apparent consumption (mill. US\$) } & \multicolumn{4}{|c|}{ Total manufactures } & \multicolumn{4}{|c|}{ Textiles } & \multicolumn{4}{|c|}{ Clothing } \\
\hline & 1980 & 1985 & 1990 & 1994 & 1980 & 1985 & 1990 & 1994 & 1980 & 1985 & 1990 & 1994 \\
\hline & \multicolumn{12}{|c|}{ European Union } \\
\hline & 2269604 & 1715524 & 3793770 & 3709476 & 91767 & 66787 & 131841 & 114334 & 50746 & 36310 & 88569 & 89834 \\
\hline External imports in $\%$ of consumption & 8.88 & 10.65 & 10.91 & 13.06 & 9.90 & 10.71 & 11.49 & 14.57 & 19.21 & 23.33 & 31.73 & 43.16 \\
\hline of which: & & & & & & & & & & & & \\
\hline Industrialized countries & 5.08 & 6.20 & 6.45 & 6.90 & 4.29 & 4.31 & 4.08 & 4.14 & 2.60 & 1.81 & 1.92 & 2.07 \\
\hline \multirow[t]{2}{*}{ Developing countries } & 2.55 & 3.12 & 3.51 & 4.57 & 4.88 & 5.60 & 6.61 & 8.90 & 14.41 & 19.05 & 27.27 & 34.66 \\
\hline & \multicolumn{12}{|c|}{ United States and Canada } \\
\hline Apparent consumption (mill. US\$) & 2011874 & 2595480 & 3272683 & 3802392 & 61528 & 76047 & 94975 & 113260 & 47441 & 64170 & 80257 & 95207 \\
\hline External imports in $\%$ of consumption & 6.99 & 9.92 & 11.76 & 13.81 & 5.09 & 7.61 & 7.98 & 8.81 & 15.86 & 26.82 & 36.30 & 42.30 \\
\hline of which: & & & & & & & & & & & & \\
\hline Industrialized countries & 4.39 & 6.31 & 6.81 & 7.18 & 2.50 & 3.84 & 3.34 & 3.33 & 1.72 & 3.85 & 3.36 & 2.80 \\
\hline \multirow[t]{2}{*}{ Developing countries } & 2.53 & 3.54 & 4.84 & 6.43 & 2.48 & 3.68 & 4.55 & 5.33 & 13.91 & 22.72 & 32.74 & 39.10 \\
\hline & \multicolumn{12}{|c|}{ Japan } \\
\hline Apparent consumption (mill. US\$) & 879492 & 994157 & 2106795 & 2871224 & 36621 & 36222 & 63095 & 75049 & 11519 & 12371 & 30775 & 43806 \\
\hline External imports in $\%$ of consumption & 5.33 & 5.33 & 6.77 & 6.35 & 5.59 & 6.72 & 7.79 & 7.96 & 13.38 & 16.32 & 38.57 & 34.93 \\
\hline Industrialized countries & 3.21 & 3.34 & 4.15 & 3.57 & 2.39 & 2.63 & 3.55 & 2.56 & 3.76 & 2.81 & 7.03 & 6.43 \\
\hline Developing countries & 2.01 & 1.90 & 2.50 & 2.70 & 3.14 & 4.05 & 4.18 & 5.38 & 9.60 & 13.49 & 21.51 & 28.48 \\
\hline
\end{tabular}

Source: Based on UNCTAD (1997: Tab. 7.1). 
Table 6 - Overview of Computable General Equilibrium Assessments of the Uruguay Round ${ }^{\mathrm{a}}$ - Sectoral Distribution of Welfare Effects (in Percent)

\begin{tabular}{|c|c|c|c|c|c|c|c|}
\hline \multirow[t]{2}{*}{ Studyb/ } & \multirow{2}{*}{ Model $^{\mathrm{c}}$} & \multicolumn{6}{|c|}{ Sectors specified } \\
\hline & & Agriculture & Primary & MFA & Manufact. & Services & Tariffs \\
\hline \multicolumn{2}{|l|}{1.} & 5 & & 14 & & & 81 \\
\hline 2. & $\begin{array}{l}\mathrm{I}^{\mathrm{d}} \\
\mathrm{II}^{\mathrm{e}} \\
\mathrm{IIII}^{\mathrm{f}}\end{array}$ & $\begin{array}{l}68 \\
38 \\
61\end{array}$ & & $\begin{array}{l}15 \\
12 \\
17\end{array}$ & $\begin{array}{l}18 \\
49 \\
23\end{array}$ & & \\
\hline 3. & $\begin{array}{l}\mathrm{Ig} \\
\mathrm{II}^{\mathrm{h}} \\
\mathrm{IIII}^{\mathrm{h}}\end{array}$ & $\begin{array}{l}9 \\
3 \\
3\end{array}$ & $\begin{array}{l}3 \\
6 \\
7\end{array}$ & $\begin{array}{l}35 \\
61 \\
50\end{array}$ & $\begin{array}{l}53 \\
30 \\
39\end{array}$ & & \\
\hline 4. & $\begin{array}{l}\mathrm{I}^{\mathrm{g}} \\
\mathrm{II}^{\mathrm{h}}\end{array}$ & $\begin{array}{l}31 \\
10\end{array}$ & & $\begin{array}{l}39 \\
64\end{array}$ & & & $\begin{array}{l}30 \\
26\end{array}$ \\
\hline 5. & $\begin{array}{l}\text { I } \\
\text { II }\end{array}$ & $\begin{array}{l}46 \\
26\end{array}$ & & $\begin{array}{l}29 \\
37\end{array}$ & & & $\begin{array}{l}24 \\
37\end{array}$ \\
\hline 6. & & 34 & & 40 & & 14 & 12 \\
\hline $\begin{array}{l}\text { a Drawn } \\
\text { Hertel et } \\
\text { Yang (19 } \\
\text { differing } \\
\text { the struct } \\
\text { (PC). - g }\end{array}$ & $\begin{array}{l}\text { from Frar } \\
\text { al. (1995 } \\
94) ; 6= \\
\text { assumptic } \\
\text { ure and tl } \\
\text { Steady st }\end{array}$ & $\begin{array}{l}\text { et al. (1996, } \\
=\text { Harrison et } \\
\text { en et al. (199 } \\
\text { he reader is ac } \\
\text { derlying assu } \\
\text { h Steady state }\end{array}$ & $\begin{array}{l}\text { ble 1, last } \\
\text { (1995); } 3 \\
-{ }^{\mathrm{c}} \text { The } \\
\text { ised to refe } \\
\text { ptions. - d } \\
\text { no PC. }\end{array}$ & $\begin{array}{l}\mathrm{mn} \text { ); ple } \\
\text { ançois } \\
\text { an nume } \\
\text { the orig } \\
\text { ic. }-\mathrm{e}^{\mathrm{I}}\end{array}$ & $\begin{array}{l}\text { ee original } \\
\text { (1995); } 4= \\
\text { designate } \mathrm{m} \\
\text { ables in the } \\
\text { mic. }-{ }^{f} \text { Sta }\end{array}$ & $\begin{array}{l}\text { specifics. } \\
\text { ançois et } \\
\text { el runs car } \\
\text { icles to exa } \\
\text { not perfe }\end{array}$ & $\begin{array}{l}\text { Study: } 1= \\
994) ; 5= \\
\text { out under } \\
\text { e in depth } \\
\text { mpetition }\end{array}$ \\
\hline
\end{tabular}


vii

Table 7 - Tariff Concessions Given and Received: Post Uruguay Round Tariff Rates ${ }^{\mathrm{a}}$ and Percent Reductions ${ }^{b}$ by Selected Countries

\begin{tabular}{|c|c|c|c|c|c|c|c|c|c|c|c|c|}
\hline \multirow{2}{*}{$\begin{array}{l}\text { Product } \\
\text { category }\end{array}$} & \multicolumn{2}{|c|}{ Canada } & \multicolumn{2}{|c|}{$\mathrm{EU}(12)$} & \multicolumn{2}{|c|}{ Japan } & \multicolumn{2}{|c|}{ USA } & \multicolumn{2}{|c|}{$\mathrm{LMIE}^{\mathrm{c}}$} & \multicolumn{2}{|c|}{$\mathrm{HIE}^{\mathrm{c}}$} \\
\hline & $\begin{array}{l}\text { Tariff } \\
\text { rate }\end{array}$ & $\begin{array}{l}\text { Percent } \\
\text { reduc- } \\
\text { tion }\end{array}$ & $\begin{array}{l}\text { Tariff } \\
\text { rate }\end{array}$ & $\begin{array}{l}\text { Percent } \\
\text { reduc- } \\
\text { tion }\end{array}$ & $\begin{array}{l}\text { Tariff } \\
\text { rate }\end{array}$ & $\begin{array}{l}\text { Percent } \\
\text { reduc- } \\
\text { tion }\end{array}$ & $\begin{array}{l}\text { Tariff } \\
\text { rate }\end{array}$ & $\begin{array}{l}\text { Percent } \\
\text { reduc- } \\
\text { tion }\end{array}$ & $\begin{array}{l}\text { Tariff } \\
\text { rate }\end{array}$ & $\begin{array}{l}\text { Percent } \\
\text { reduc- } \\
\text { tion }\end{array}$ & $\begin{array}{l}\text { Tariff } \\
\text { rate }\end{array}$ & $\begin{array}{l}\text { Percent } \\
\text { reduc- } \\
\text { tion }\end{array}$ \\
\hline & \multicolumn{12}{|c|}{ Tariff concessions given } \\
\hline Agriculture $^{\mathrm{d}}$ & 7.0 & - & 15.7 & 5.9 & 65.1 & 36.6 & 10.8 & 1.5 & 17.4 & 43.0 & 26.9 & 26.9 \\
\hline Textiles/clothing & 14.2 & 5.7 & 8.7 & 2.0 & 7.2 & 2.3 & 14.8 & 2.0 & 21.2 & 8.5 & 8.4 & 2.6 \\
\hline Metals & 1.5 & 5.5 & 1.0 & 3.3 & 0.5 & 2.1 & 1.1 & 3.8 & 10.8 & 9.5 & 0.9 & 3.4 \\
\hline Chemicals, etc. ${ }^{\mathrm{e}}$ & 2.6 & 5.9 & 3.8 & 3.3 & 1.2 & 2.5 & 2.5 & 4.9 & 12.4 & 9.7 & 2.2 & 3.7 \\
\hline Transportation equip. & 3.2 & 3.0 & 5.5 & 2.4 & 0.0 & 3.9 & 3.4 & 1.1 & 19.9 & 10.1 & 4.2 & 2.6 \\
\hline NE machinery $\mathrm{f}$ & 1.2 & 4.1 & 1.4 & 3.0 & 0.0 & 3.9 & 0.9 & 2.8 & 13.5 & 6.5 & 1.1 & 3.1 \\
\hline Electric machinery & 1.6 & 5.3 & 5.4 & 3.5 & 0.1 & 2.3 & 1.7 & 2.5 & 14.6 & 7.7 & 2.3 & 3.2 \\
\hline Industrial goods & 2.6 & 4.8 & 2.9 & 2.9 & 1.4 & 2.6 & 3.1 & 2.9 & 13.3 & 8.1 & 2.5 & 3.1 \\
\hline \multirow[t]{2}{*}{ All merch. trade } & 2.4 & 4.7 & 2.8 & 3.1 & 2.8 & 2.7 & 2.8 & 2.9 & 13.3 & 8.1 & 2.6 & 3.2 \\
\hline & \multicolumn{12}{|c|}{ Tariff concessions received } \\
\hline Agriculture $^{\mathrm{d}}$ & 41.2 & 40.7 & 33.6 & 52.6 & 6.6 & 13.8 & 37.6 & 46.7 & 13.3 & 17.1 & 39.5 & 40.0 \\
\hline Textiles/clothing & 7.1 & 5.3 & 11.4 & 4.3 & 8.6 & 5.9 & 9.7 & 4.8 & 8.8 & 2.7 & 10.9 & 3.9 \\
\hline Metals & 0.6 & 2.8 & 5.2 & 5.3 & 4.8 & 6.8 & 3.1 & 3.3 & 2.3 & 3.4 & 3.2 & 4.3 \\
\hline Chemicals, etc. ${ }^{\mathrm{e}}$ & 1.8 & 5.3 & 5.2 & 5.5 & 5.9 & 6.6 & 4.9 & 4.4 & 4.8 & 4.7 & 4.8 & 5.0 \\
\hline Transportation equip. & 1.0 & 4.1 & 5.0 & 3.2 & 8.3 & 3.4 & 2.3 & 3.7 & 5.6 & 2.2 & 6.5 & 3.3 \\
\hline NE machinery ${ }^{\mathrm{f}}$ & 0.8 & 3.7 & 5.4 & 3.5 & 3.9 & 3.7 & 3.0 & 3.7 & 2.9 & 3.1 & 3.6 & 3.4 \\
\hline Electric machinery & 2.4 & 4.0 & 7.9 & 3.9 & 4.7 & 3.8 & 4.9 & 4.9 & 2.7 & 3.4 & 5.0 & 3.8 \\
\hline Industrial goods & 0.6 & 4.3 & 5.3 & 4.3 & 5.2 & 4.3 & 3.3 & 4.1 & 4.0 & 3.3 & 4.4 & 3.9 \\
\hline All merch. trade & 0.8 & 4.0 & 5.5 & 4.2 & 3.5 & 3.9 & 3.8 & 4.1 & 3.9 & 3.5 & 4.5 & 3.9 \\
\hline
\end{tabular}

Source: Excerpted from Finger et al. (1996: respective country, country-goruping tables in sections G.1, G.2, R.1 and R.2). 
Table 8 - Imports of Clothing Products (SITC 84) for Selected OECD Countries by Major Suppliers: $1990-1996$ (\% of Total)

\begin{tabular}{|c|c|c|c|c|c|c|c|}
\hline & 1990 & 1991 & 1992 & 1993 & 1994 & 1995 & 1996 \\
\hline Germany (Total) ${ }^{\mathbf{a}}$ & 20,385 & 24,059 & 24,718 & 22,233 & 22,755 & 24,591 & 24,066 \\
\hline$E U^{b}$ & 37.92 & 35.56 & 36.95 & 30.36 & 29.94 & 29.02 & 28.08 \\
\hline Non-EU & 60.02 & 62.46 & 60.88 & 67.43 & 67.95 & 68.79 & 68.89 \\
\hline Euro-Med $^{\mathrm{d}}$ & 29.01 & 27.40 & 28.77 & 32.68 & 34.11 & 37.64 & 38.44 \\
\hline Med. ${ }^{\mathrm{e}}$ & 14.47 & 13.46 & 14.51 & 15.84 & 15.47 & 17.25 & 17.49 \\
\hline CE-Eurof & 14.54 & 13.93 & 14.25 & 16.82 & 18.61 & 20.26 & 20.91 \\
\hline Asiag & 29.55 & 35.89 & 33.52 & 36.50 & 35.94 & 33.59 & 34.38 \\
\hline E-Asiah & 20.11 & 22.54 & 19.44 & 20.36 & 19.48 & 16.81 & 17.11 \\
\hline UK (Total) $^{\mathbf{a}}$ & 6,890 & 7,210 & 7,763 & 6,743 & 7,413 & 8,017 & 9,405 \\
\hline $\mathrm{EU}^{\mathrm{b}}$ & 42.81 & 39.04 & 38.35 & 27.65 & 29.04 & 29.75 & 31.08 \\
\hline Non-EU ${ }^{c}$ & 54.71 & 58.46 & 58.98 & 69.66 & 68.26 & 67.44 & 66.02 \\
\hline Euro-Med ${ }^{d}$ & 10.35 & 9.72 & 10.51 & 11.88 & 12.66 & 13.92 & 14.06 \\
\hline Med. ${ }^{\mathrm{e}}$ & 8.61 & 7.87 & 8.26 & 9.15 & 9.35 & 10.17 & 10.15 \\
\hline CE-Eurof & 1.74 & 1.84 & 2.25 & 2.73 & 3.29 & 3.73 & 3.90 \\
\hline Asiag & 41.24 & 45.24 & 44.38 & 53.21 & 51.54 & 49.10 & 47.74 \\
\hline E-Asiah & 24.85 & 27.55 & 25.30 & 30.46 & 28.00 & 25.04 & 24.56 \\
\hline Italy (Total) $^{\mathbf{a}}$ & 2,559 & 3,418 & 4,294 & 3,822 & 3,964 & 4,650 & 4,991 \\
\hline$E U^{b}$ & 49.81 & 45.19 & 42.53 & 37.62 & 36.03 & 31.97 & 31.20 \\
\hline Non-EU ${ }^{\mathrm{c}}$ & 44.11 & 49.47 & 53.09 & 58.54 & 61.01 & 65.62 & 66.01 \\
\hline Euro-Med ${ }^{d}$ & 13.52 & 15.26 & 19.25 & 23.00 & 27.72 & 31.05 & 34.52 \\
\hline Med. ${ }^{\mathrm{e}}$ & 7.26 & 8.40 & 9.82 & 11.57 & 13.48 & 14.58 & 14.99 \\
\hline CE-Eurof & 6.25 & 6.85 & 9.38 & 11.26 & 14.08 & 16.26 & 19.08 \\
\hline Asiag & 27.23 & 31.15 & 30.75 & 32.62 & 30.22 & 31.56 & 28.47 \\
\hline E-Asiah & 16.02 & 17.78 & 17.13 & 17.68 & 15.26 & 15.00 & 14.28 \\
\hline Sweden (Total) ${ }^{\mathbf{a}}$ & 2,514 & 2,460 & 2,622 & 2,096 & 2,116 & 2,127 & 2,169 \\
\hline $\mathrm{EU}^{\mathrm{b}}$ & 62.14 & 58.87 & 55.34 & 45.66 & 43.08 & 43.85 & 44.53 \\
\hline Non-EUc & 35.25 & 38.33 & 41.94 & 51.59 & 54.59 & 50.38 & 51.13 \\
\hline Euro-Med ${ }^{d}$ & 4.69 & 5.31 & 7.57 & 8.08 & 9.75 & 10.71 & 12.15 \\
\hline Med. ${ }^{\mathrm{e}}$ & 2.33 & 1.84 & 2.19 & 2.17 & 2.33 & 2.05 & 2.66 \\
\hline CE-Eurof & 2.37 & 3.46 & 5.38 & 5.91 & 7.43 & 8.65 & 9.50 \\
\hline Asiag & 29.32 & 31.77 & 33.46 & 42.37 & 43.92 & 38.99 & 38.13 \\
\hline E-Asiah & 21.39 & 23.75 & 25.04 & 32.55 & 33.31 & 29.06 & 28.74 \\
\hline USA $(\text { Total })^{\mathbf{a}}$ & 26,977 & 27,696 & 32,951 & 35,605 & 38,643 & 41,367 & 43,320 \\
\hline $\mathrm{EU}^{\mathrm{b}}$ & 7.00 & 5.88 & 4.95 & 4.40 & 4.61 & 4.84 & 5.17 \\
\hline Non-EU⿱ & 91.21 & 92.13 & 93.05 & 93.43 & 93.00 & 92.51 & 92.29 \\
\hline Euro-Med ${ }^{d}$ & 3.02 & 2.57 & 2.92 & 3.20 & 3.88 & 4.34 & - \\
\hline Asiag & 74.31 & 73.54 & 72.33 & 70.49 & 67.69 & 63.24 & 61.50 \\
\hline E-Asiah & 53.38 & 52.36 & 48.54 & 46.07 & 43.14 & 37.99 & - \\
\hline Latin America ${ }^{1}$ & 12.47 & 14.75 & 15.99 & 17.61 & 19.04 & 22.44 & 24.88 \\
\hline
\end{tabular}

Source: OECD, 1998 CD-ROM. 


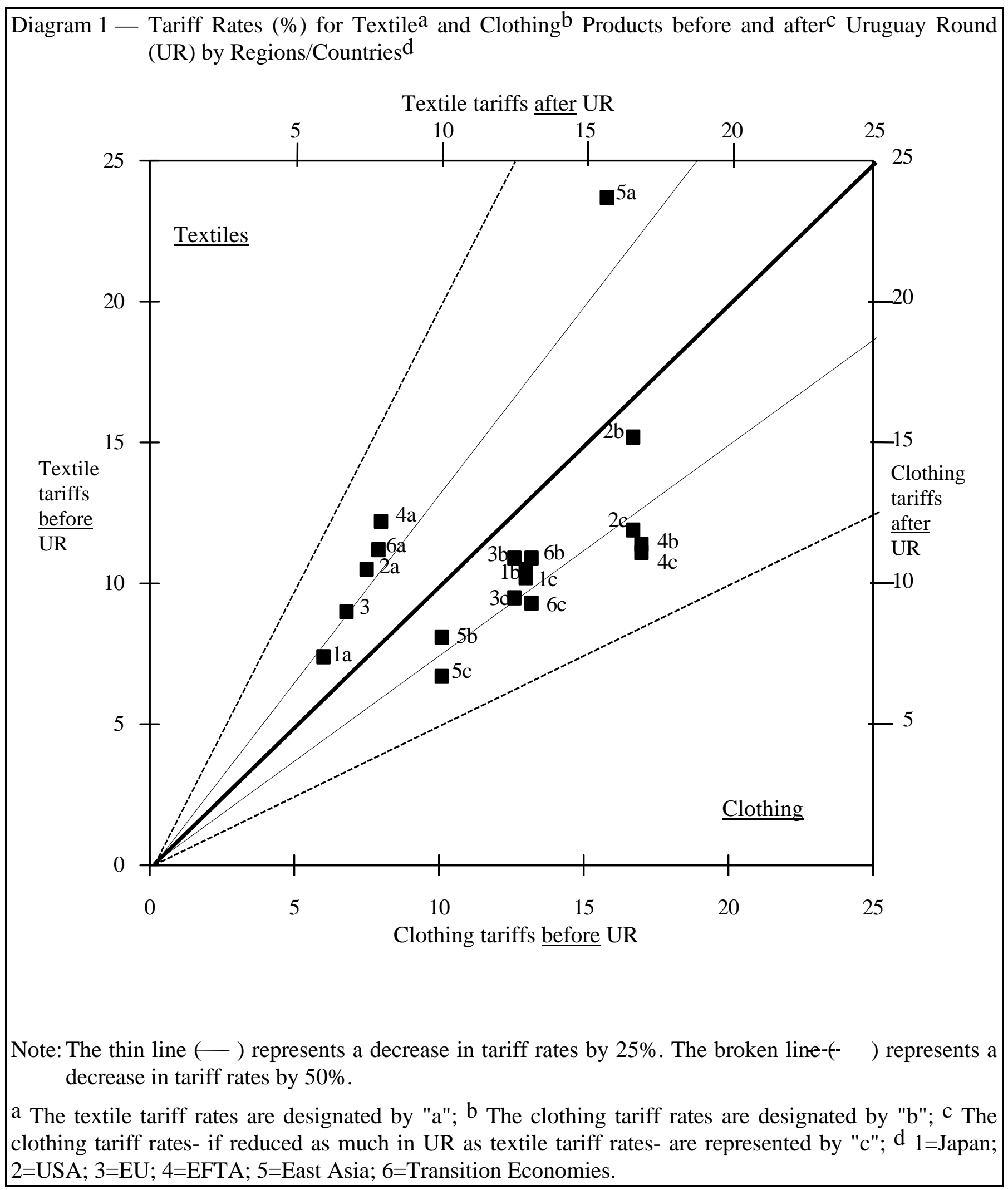




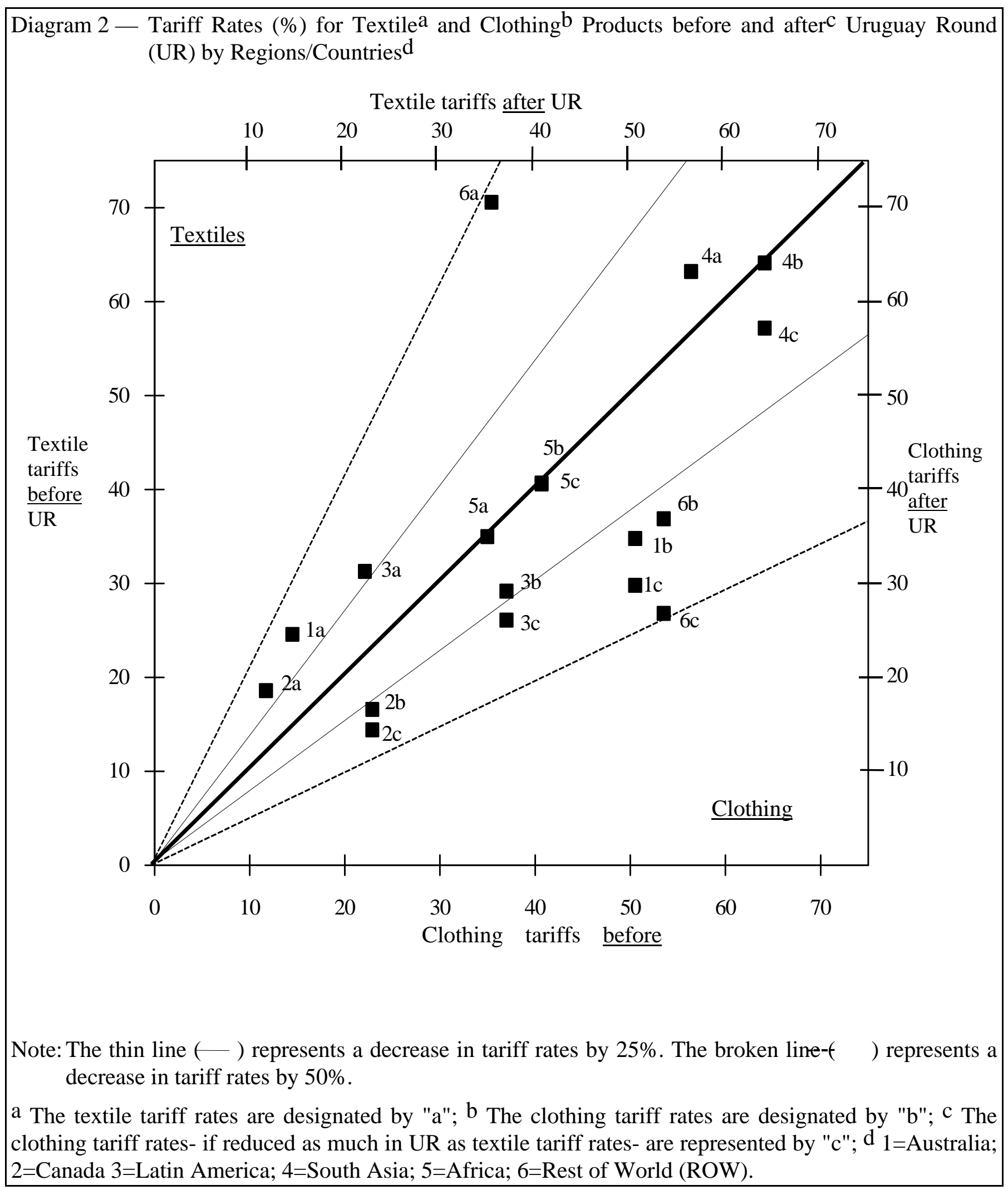


Diagram 3 - Per Capita Clothing Imports (US\$) ${ }^{\mathrm{a}}$ : Total and from NON-ICs ${ }^{\mathrm{b}}$

\section{Total}
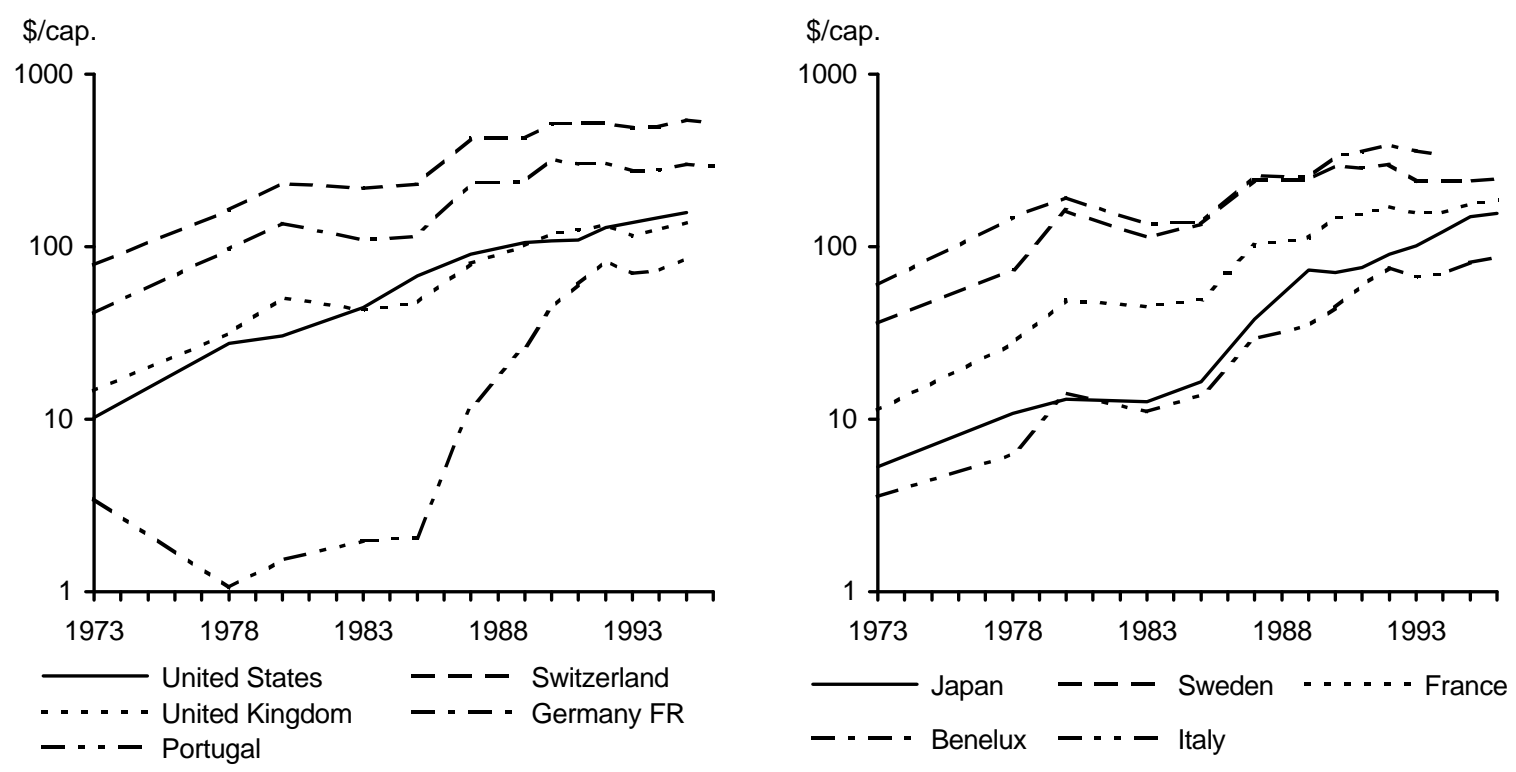

\section{Non-ICs}
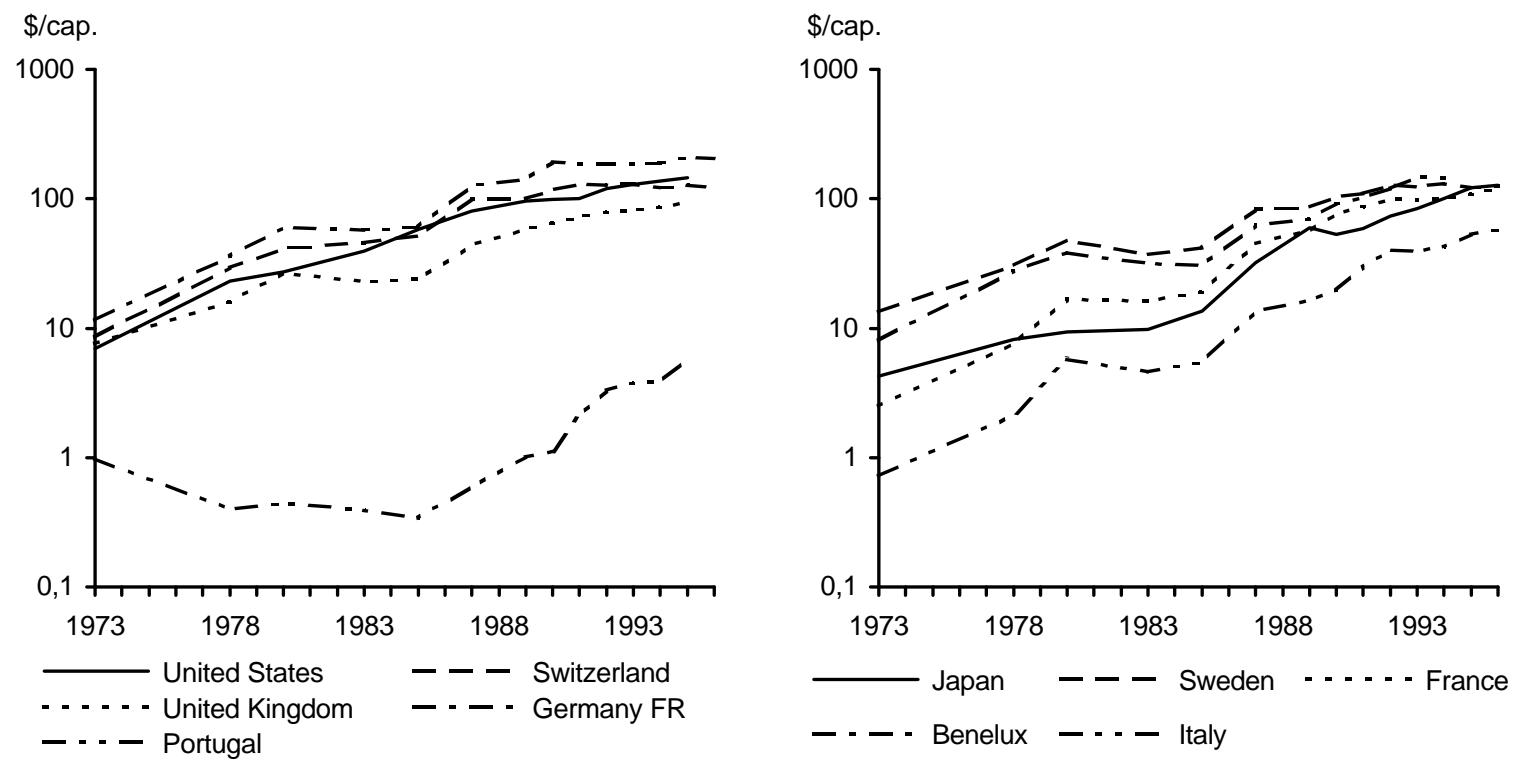

${ }^{\mathrm{a}}$ Imports of SITC 84 in US $\$$ divided by population.- ${ }^{\mathrm{b}}$ Non-ICs compromise all countries except those on OECD (excluding Turkey); Germany is Federal Republic (i.e. West Germany) through 1990.

Source: Own calculations based on OECD, Trade by commodities CDROM (for trade), UNCTAD tabulations (for trade) and IMF, International Financial Statistics (for population). 